\title{
'Let no-one ignorant of geometry...': Mathematical parallels for understanding the objectivity of ethics
}

\author{
James Franklin
}

Journal of Value Inquiry, 2021

Abstract: It may be a myth that Plato wrote over the entrance to the Academy "Let no-one ignorant of geometry enter here." But it is a well-chosen motto for his view in the Republic that mathematical training is especially productive of understanding in abstract realms, notably ethics. That view is sound and we should return to it. Ethical theory has been bedevilled by the idea that ethics is fundamentally about actions (right and wrong, rights, duties, virtues, dilemmas and so on). That is an error like the one Plato mentions of thinking mathematics is about actions (of adding, constructing, extracting roots and so on). Mathematics is about eternal relations between universals, such as the ratio of the diagonal of a square to the side. Ethics too is about eternal verities, such as the equal worth of persons and just distributions. Mathematical and ethical verities do both constrain actions, such as the possibility of walking over the seven bridges of Königsberg once and once only or of justly discriminating between races. But they are not themselves about action. In principle, neither mathematical nor ethical verities are subject to historical forces or disagreement among tribes (though they can be better understood as time goes on). Plato is right: immersion in mathematics induces an understanding of the necessities underpinning reality, an understanding that is essential for distinguishing objective ethics from tribal custom. Equality, for example, is an abstract concept which is foundational for both mathematics and ethics.

Keywords: mathematics and ethics; Plato's Republic; equality of persons; worth of persons; symmetry arguments; evolutionary game theory 


\section{Introduction}

For those seeking to defend the objectivity of ethics within a realist framework, ${ }^{1}$ emphasising its parallels with mathematics is an attractive line of argument. Arguments for ethical relativism arising from the mere fact that ethical principles are held by people and have evolved through natural causes face the objection that mathematical truths do not have their objectivity impugned by similar considerations. ${ }^{2}$ The fact that ethical knowledge (if there is any) seems to be a priori, arising from pure thinking rather than measurement or scientific observation, is also something it shares with mathematical knowledge, ${ }^{3}$ so cannot in itself tell against the objectivity of ethics.

There are certainly some obstacles that stand in the way of using the parallel with mathematics to bolster objectivist views of ethics. Some philosophies of both ethics and mathematics undermine the parallel. For example, non-cognitivist philosophies of ethics that see it as fundamentally a set of techniques about action developed for evolutionary and social reasons, as "traffic rules for self-assertors", ${ }^{4}$ deny that ethics is a body of truths about a subject matter. From the other direction, some popular anti-realist philosophies of mathematics also deny that mathematics is a genuinely contentful science of a subject matter. At one time Peter Singer argued:

The defenders of ethical intuitionism argued that there was a parallel in the way we know or could immediately grasp the basic truths of mathematics: that one plus one equals two, for instance. This argument suffered a blow when it was shown that the self evidence of the basic truths of mathematics could be explained in a different and more parsimonious way, by seeing mathematics as a system of tautologies, the basic elements of which are true by virtue of the meanings of the terms used. On this view, now widely, if not universally, accepted, no special intuition is required to establish that one plus one equals 
two - this is a logical truth, true by virtue of the meanings given to the integers 'one' and 'two', as well as 'plus' and 'equals'. So the idea that intuition provides some substantive kind of knowledge of right and wrong lost its only analogue. ${ }^{5}$

That philosophy of mathematics is not universally or even widely accepted. In fact it has had hardly any adherents in philosophy since Frege and Russell found it untenable over a hundred years ago. ${ }^{6}$ But the persistence of such views does show that realist philosophies of mathematics cannot be taken for granted any more than realist philosophies of ethics can be. Indeed, one could in principle use the mathematics-ethics analogy to support an anti-realist or pluralist view of both. ${ }^{7}$ Justin Clarke-Doane's pluralist view based on accepting close parallels between mathematics and ethics will be considered in section 5 below.

To understand the possibilities for comparing realist approaches to ethics and mathematics, we need to return to the source, Plato's Republic.

\section{Plato's Mathematical "Good"}

Plato's idea is that insight into the necessities of mathematics is apt for training the mind to love the necessities of ethics. The reason for that is the close connection between ethical and mathematical truths. Hence the ruler well-trained in mathematics is motivated to make this world conform to those necessities, as far as possible.

What we have to consider is whether the greater and more advanced part of [mathematics] tends to facilitate the apprehension of the idea of good. That tendency, we affirm, is to be found in all studies that force the soul to turn its vision round to the region where dwells the most blessed part of reality, which it is imperative that it should behold. ${ }^{8}$ 
That is the thought summarized in the inscription over the entrance to the Academy, "Let noone ignorant of geometry enter here." The inscription is probably apocryphal, ${ }^{9}$ but has always been recognized as an accurate slogan for Plato's thought.

Plato's treatment is inspiring for any attempt to revive the connection between mathematics and ethics, though also disappointing because of his alien view of the nature of the Good.

Plato adds some explanation of what it is exactly about mathematics that trains the intellectual powers of the mind in a certain way. The relevant aspects of mathematics are not, for example, its being about quantity, or even its being organized as a structure of theorems derived from axioms. It is instead something about how the act of understanding in mathematics leads the mind to contemplate the purely intelligible realities that stand behind appearances. What mathematicians see, such as drawn lines in diagrams, is one thing, what they understand by them is another. He writes:

[mathematicians] further make use of the visible forms and talk about them, though they are not thinking of them but of those things of which they are a likeness, pursuing their inquiry for the sake of the square as such and the diagonal as such, and not for the sake of the image of it which they draw. And so in all cases. The very things which they mould and draw, which have shadows and images of themselves in water, these things they treat in their turn as only images, but what they really seek is to get sight of those realities which can be seen only by the mind..$^{10}$

That is correct. Geometrical knowledge involves an intellectual "rectification" of imprecise perceptual experience. We can gain the idea of a perfect square by looking at imperfect squares, and we then see imperfect squares as approximating perfect ones. The geometrical knowledge that Plato extracts from the slave-boy in the Meno is of the relation of perfect squares, although the diagrams drawn by the participants are far from perfect squares. The incommensurability 
of the diagonal and side of a perfect square has no meaning for the approximate squares drawn to illustrate it; incommensurability is not detectable by the senses. ${ }^{11}$ Mathematical knowledge thus trains the mind to see "realities which can be seen only by the mind," though ones which cast light on the realities that are seen by the eye.

Ethics too involves a comparison between what is, which can be seen "by the eye", and what ought to be, which can in general only be understood, that is, grasped by an intellectual operation (which is not to deny the existence of moral perception in some cases, parallel to the perception of the simplest mathematical necessities ${ }^{12}$ ). If a distribution of resources differs from a just division, the actual distribution can be measured but the just one is a standard recognisable only by thought. If an act of killing was in self-defence, that fact can be established without moral input, but whether it was justified requires reference to an outside ethical standard which can only be accessed by the mind. Thus training in the necessities of mathematics has at least the potential to induce an appreciation of the difference between observational facts and abstract standards which can be appreciated only by the understanding.

It is true that the content of Plato's ethical thought is disappointing, from a present-day ethical perspective. What is alien about Plato's (and Aristotle's) ethics is its lack of two ingredients that post-Christian ethics takes to be foundational of any ethical project - the equality of persons $^{13}$ and the virtue of charity or benevolence. Aquinas, in synthesising Christian ethics with the classical inheritance, has to add to the ancient "philosophical" virtues the three "theological" virtues of faith, hope and charity. It is clear enough why faith and hope should be theological virtues, but the fact that caritas (covering the whole field of our love, charity, benevolence and care) has to be added reveals a large hole in Greek ethics. ${ }^{14}$ And even the philosophical virtue of "justice" does not, in Greek ethics, have the modern implication that the equality of persons demands equal and thus just treatment of each. Plato's "justice" is much 
more an attunement or harmony of society, such as when artisans and guardians both know their place and fulfil their mutually beneficial roles.

Plato's model of the Good is thus more like harmony in music. ${ }^{15}$ Harmony can be heard and can sound beautiful, but the superior science of music involves an intellectual study of why that is so, of the mathematics of integer ratios such as the octave and fifth that explain (heard) harmony. 16 "Ethics" is then modelled as harmony - that is, on the mathematical system of ratios that stands behind heard harmonies and so can be realized in other categories (such as planetary motions). Justice is defined as an attunement, in the first instance in the soul ${ }^{17}$ and later in the structure of the perfect state.

Thus in Plato, "the Good is described formally, even mathematically, it is ratio." Or at least, if the Good is strictly speaking ineffable, "Measure is the Good in so far as it can be grasped by reason." 18 The kind of thing to be expected when this world imitates the Good as far as it can is the heavenly bodies' using spheres and circles because those are the best of all shapes. ${ }^{19}$

Aristotle's mathematical account of "justice" betrays the same close conceptual connection between the "just" and ratio as in Plato, even though it does discuss cases of justice that are closer to our ethical meaning of the word, such as compensation for fraud. His argument that a just division is a proportional one does not rely on any ethical premises. The reason he gives is simply that the just is a species of the proportional and he feels that needs no further justification. ${ }^{20}$

To modern ethical sensibilities, Plato and to a lesser extent Aristotle have moved far beyond what can be called genuinely ethical. The Good is, as Plato puts it, "greater than justice and the other virtues." 21 To the extent that their discussion is about the Good at all, it is closer to what we would call the aesthetic than the ethical good (with the aesthetic good being interpreted realistically, not as a matter of human response). Indeed Aquinas, again building on classical 
ideas, says that the bases of the beautiful are proportion, brightness (or radiance) and integrity (or non-defectiveness). ${ }^{22}$ The core meaning of the first of these is strictly mathematical, involving ratios and symmetries in naturally beautiful things and in visual art, and numerical harmonies in music. ${ }^{23}$

Thus Plato comes close to actually identifying the Good with something mathematical. That renders his ideas less than adequate for understanding what we take ethics to be.

It is therefore necessary to separate the two parts of Plato's vision. His claim that study of mathematics is useful for appreciating eternal verities in ethics and elsewhere can be accepted without the need to accept his particular "mathematico-aesthetic" concept of the Good. In searching for realist foundations of ethics and their relation to mathematics, we will need to start again. ${ }^{24}$

\section{Mathematics and Eternal Verities: Realist Philosophies of Mathematics}

Traditionally, mathematics has been taken to be the study of eternal truths about an objective subject-matter. The incommensurability of the diagonal and side of a square, the logarithmic decay of the density of primes, and the existence of exactly 26 sporadic finite simple groups, appear to be unchanging, provably true facts about a terrain of mathematical entities that exists independently of human actions, knowledge or wishes. As Plato says, it would be ludicrous to interpret mathematicians' talk of actions like adding numbers, constructing circles and extracting square roots as implying that mathematics is really about action. It is pure knowledge, "the knowledge of that which always is, and not of a something which at some time comes into being and passes away." 25 Arithmetic is normative for the actions of addingup by accountants, but it is itself neither essentially normative nor about actions. 
Realist philosophies of mathematics offer various accounts of what eternal verities mathematics is in fact about (in contrast to nominalist philosophies which represent mathematics as a mere language of science, or method of deriving one substantive scientific truth from others, or manipulation of uninterpreted symbols). The most prominent realist philosophy of mathematics is Platonism, according to which numbers, sets and the like are classical "abstract objects": acausal, atemporal objects existing necessarily in a Platonic realm, neither physical nor mental. ${ }^{26}$ Since Platonism (in and outside the philosophy of mathematics) is subject to a number of classic objections, it should be noted that there is an alternative realist philosophy of mathematics, Aristotelianism, which takes mathematics to be as necessarily true and contentful as does Platonism, but also takes it to be about properties of the physical world (and any other non-abstract world there may be) - properties such as symmetry, ratio, pattern, continuity and flow. ${ }^{27}$

It would take us too far afield to adjudicate between philosophies of mathematics. But the following example, a favourite of the Aristotelian school, shows in a simple way how provable mathematical necessities constrain what can happen in the physical world. That provides a model of how other abstract truths, such as ethical ones, can also bear on what is possible in the real world; and hence, how our understanding of such abstract truths can give us insight into the necessities inherent in the real world.

In the early eighteenth century, the seven bridges of Königsberg (home of the young Kant) connected two islands and two riverbanks as shown schematically in Fig 1. 


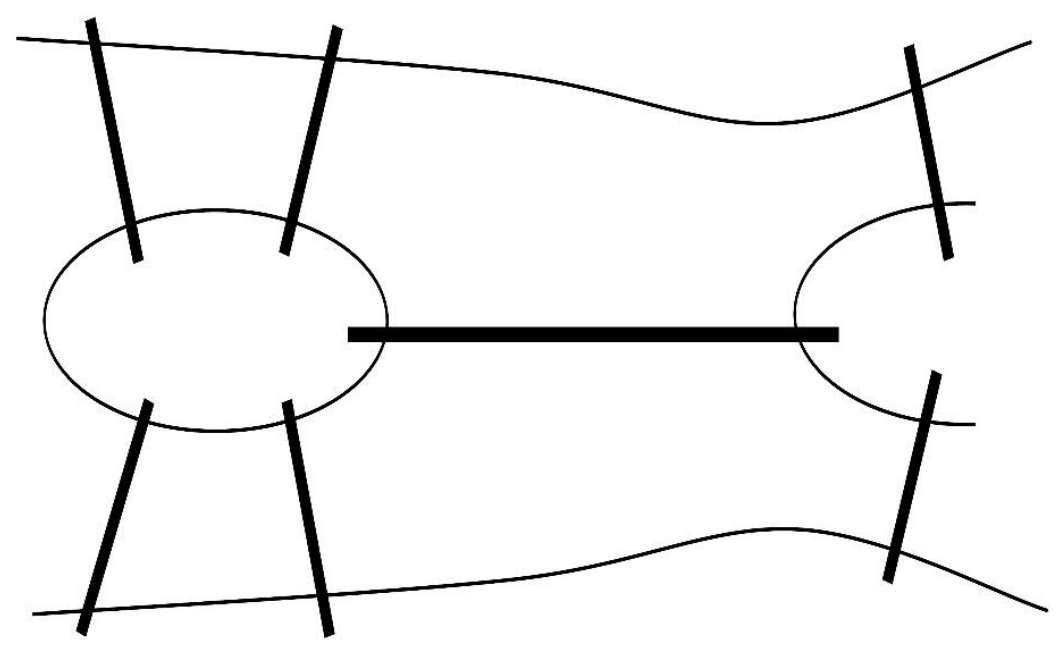

Fig 1 The bridges of Königsberg

The citizens of that city noticed that it was impossible to walk over all the bridges once, without walking over at least one of them twice. Euler proved they were correct. (The essential idea of his proof is that walking into and out of a land area uses up two bridges, but since all the land areas have an odd number of bridges out of them, it is impossible to match up ins and outs to create a path over all the bridges without reusing some. ${ }^{28}$ His proof applies directly the system of the bridges, not to any idealisation or abstraction of them.

What one learns from mathematical examples like the Königsberg bridges is that there exists a world of necessities, understandable by pure thought, which have consequences in constraining the real (non-abstract) world. Mathematical necessities do not live just in a Platonic realm of "pure" mathematics but in our physical world. ${ }^{29}$ That opens one's mind to becoming attuned to the necessities of ethical reality. 
That is not to claim that ethical necessity and mathematical necessity are identical. If it is mathematically impossible to walk over all the bridges just once, one does not have the choice of doing it. But if it were impossible to walk over all the bridges justly, one could still choose to walk over them. Ethical necessities constrain what it is possible to do rightly, which is not the same as constraining what it is possible to do mathematically or physically. But then one can ignore mathematical necessities if one chooses, for example the fact that $1+1=2$ does not constrain accountants to always add $\$ 1$ and $\$ 1$ and get $\$ 2$.

\section{Ethics and Eternal Verities: The Good Versus the Right}

Traditionally, ethics has not been understood as the study of eternal truths about an independently existing objective subject-matter in the way mathematics has been. It has been usual to see ethics as (solely or largely) about human actions - their rightness, their obligatoriness, what is a duty and what is permitted, which are virtuous. Even realist ethical positions that take it to be an objective matter which actions are right, such as Kantian universalisability or classical utilitarianism, suppose that it is fundamentally actions (or actionoriented virtues) that exhibit moral qualities such as rightness.

But to appreciate what Plato's perspective has to offer in comparing mathematics with ethics, we need to follow him in seeing what is ethically admirable or criticisable as in the first instance something prior to actions. His choice is that ethics is centrally about excellence of character (arete) and the "just" ordering of the state. We need not accept those particular choices, much less Plato's views on what constitutes excellence, to understand the general point that ethics is not fundamentally about what to do - even though the fundamental ethical facts have consequences for what to do and right action is certainly an important part of ethics. 
There are two basic reasons for thinking that. Firstly, what we are most disturbed by ethically - what most violently forces itself on us as ethically objective - is not anything to do with actions, but the terribleness of suffering. What makes something a tragedy is first and foremost the happening of serious evil to some being of worth.

Secondly, whenever we ask why some action is right or wrong, we find we are led back to reasons that are not themselves about action but concern the good or evil of those affected. For example, what makes the act of killing wrong is in the first place the evil of the death of the victim (rather than the action's violating some rule or being contrary to some virtue). That explains why the rule against killing can be relaxed in the case of killing in self-defence, since then there is a conflict between the evils of the death of the victim and the death of the attacker.

While the emphasis on actions and their evaluation has dominated ethics, two of its leading figures, Kant and Moore, stood for a position where the "good" (what was of moral worth in itself) contrasted with the "right", which concerned actions. Moore states the contrast as a main theme of his Principia Ethica:

I have tried in this book to distinguish clearly two kinds of question, which moral philosophers have always professed to answer, but which, as I have tried to shew, they have almost always confused both with one another and with other questions. These two questions may be expressed, the first in the form: What kind of things ought to exist for their own sakes? the second in the form: What kind of actions ought we to perform? ${ }^{30}$

Kant too, though discussing at length duties, rules and respect, sees at the bottom of ethics something not itself about actions, namely the dignity or worth of persons, which "exacts" respect and duties:

Man regarded as a person, that is, as the subject of a morally practical reason, is exalted above any price, for as a person he is not to be valued merely as a means to the ends of 
others, or even to his own ends, but as an end in himself, that is, he possesses a dignity (Würde) (an absolute inner worth (Werth)) by which he exacts respect for himself from all other rational beings in the world. He can measure himself with every other being of this kind and value himself on a footing of equality with them. ${ }^{31}$

If "what ought to exist for its own sake" and "absolute inner worth" are objective notions at all, as Moore and Kant think, they must be the kinds of eternal verities of which Plato speaks, ethical counterparts of the verities that mathematics deals in. The same is true, indeed, of the ethical ideal of classical utilitarianism - it says that the action that contributes to the greatest happiness of the greatest number is right because the greatest happiness of the greatest number is an external absolute ideal (itself unrelated to action). In general, there are many things which are ends of action because we take them to be valuable in themselves - survival, health, artworks, the preservation of ecosystems, tenure. Aristotelian ethicists particularly emphasize the perfecting of human rational powers as a good for humans $s^{32}$ - and the notion of a perfection is one that is both paradigmatically ethical and paradigmatically not about action. The inherent value of these goods is what gives actions that promote them their ethical point.

As with the philosophy of mathematics, it would take us too far afield to examine the realist options in the philosophy of the ethical good. One well-developed contemporary example is Nicholas Wolterstorff's theory that locates natural rights in the respect due to the worth of the rights-holder, and holds the kind of entity having worth to be one having such human qualities as the capacity for rational agency and an inner life of thoughts and awareness of thoughts. ${ }^{33}$ Such theories typically assert the equal worth of persons and regard that as a fact rather than a commitment. 


\section{Objections: Clarke-Doane's Morality and Mathematics}

It is certainly possible to emphasize the parallel between mathematics and ethics without believing in unique right answers to mathematical and ethical questions, as just defended. That is the position of Justin Clarke-Doane's Morality and Mathematics. It rebuts various arguments for the lack of parallel between the two, but its view of both ethics and mathematics is close to the opposite of the one advanced here. A brief examination of its position and arguments will clarify the competing approaches to the parallel between ethics and mathematics.

Clarke-Doane's view of both mathematics and ethics is strictly speaking realist, but thoroughly pluralist. His realism consists in taking mathematical and ethical statements to be true of a mind- and language-independent subject-matter, when taken at face-value. His pluralism consists in holding that (almost) "anything goes" as to the unique truth of mathematical and ethical statements: on the model of the Parallel Postulate, they may be true or false, depending on context. He concludes that "our moral beliefs are contingent in a worrying way, and this may disqualify them from counting as safe, realistically construed. However, exactly the same thing is true of our mathematical beliefs." 34 There is one disanalogy between ethics and mathematics, however, in that ethics must issue in decision and one can only decide to do one thing, so in that special sense ethics is "objective". The contingency of mathematical beliefs can be resolved by pluralism, as can beliefs about what is right; it is just practical decisions that must achieve a unique resolution.

Clarke-Doane not unreasonably takes a degree of pluralism to be widely accepted in ethics but not in mathematics, so devotes most effort to defending it in mathematics. Certainly if pluralism in mathematics were correct, it would undermine the position advocated in this article, so his arguments need careful consideration. 
He has two arguments. One is the reference to the Parallel Postulate, which he takes to generalize to most mathematical statements. The second is taken from the disagreement observed among set theorists as to whether the Axiom of Choice, the Continuum Hypothesis and other propositions are "really" true of "the" universe of sets. The natural thing to conclude is that, like the Parallel Postulate, none is uniquely true and one may choose which of them to accept - or more accurately, one may suppose that each can be taken to be true of its own universe; that is, one accepts pluralism about the subject-matter.

These two arguments are not the same and fail for different reasons. The Parallel Postulate is not a proposition (and hence cannot be true or false), because it is underspecified. "The plane has a finite number of points" is not a proposition because it has not been specified which mathematical structure is being spoken of - the 7-point plane has a finite number of points, the Euclidean plane doesn't. Similarly, “In the Euclidean plane, given a line and a point not on the line, there is exactly one line through the point which does not meet the original line" is a proposition (the Parallel Postulate in the Euclidean plane) and is true (absolutely). Underspecification of propositions does not lead to philosophical pluralism about a subjectmatter; that would be a too-easy strategy to "prove" pluralism anywhere.

On the other hand, set theory, like number theory, has a unique intended interpretation (namely, sets) and statements such as the Axiom of Choice and the Continuum Hypothesis are intended to be true and false of that interpretation. So they are not, in their intended interpretation, underspecified. It has come to be agreed, after a century and more of work, that many of those statements are going to remain controversial and hence that the higher set theory does not admit of axiomatization by self-evident axioms and rules. One may speculate that there "exist" (in some Platonic sense) both Axiom-of-Choice and non-Axiom-of-Choice set universes, but that is itself controversial. An alternative view would be that the whole logic-based project of proofs about sets has come adrift from (Platonic) reality and there are just no very large sets, or if 
there are we know nothing about them (though it is hard to know where to draw the line: for present purposes there is no need to decide if real analysis as used in physics is certain or not). In any case, it can be conceded that beliefs about higher set theory have, in Clarke-Doane's words about mathematical beliefs in general, no "claim to being self-evident, provable, plausible or analytic".35

However, those advocating a parallel between certainty in mathematics and ethics do not propose to compare ethics with higher set theory, but with core mathematics. There is no sense in which basic mathematics, from the paradigmatic " $2+2=4$ " to the ordinary results of linear algebra and discrete optimization, is founded on the axioms of set theory. Although the name "foundations of mathematics" has been retained for historical reasons, arising from Frege and Russell's hope that mathematics might be so founded, it had become evident at least by 1910 that that was unlikely to happen. As Clarke-Doane quotes Russell, "We tend to believe the premises [i.e. set-theory axioms] because we can see that their consequences are true, instead of believing the consequences because the premises are true." 36 That only makes sense if we can in fact "see that their consequences are true," that is, have confidence that $2+2=4$ because we can see why it must be true (or in somewhat more complex cases, see how it follows from more basic truths). The proof of Euler's result about the Königsberg bridges, for example, which was briefly outlined above, does not have the Axiom of Choice lurking among the premises and threatening to undermine it. It proceeds from evident premises, observably true of physical bridges, by evident steps. ${ }^{37}$

Clarke-Doane does in fact admit that it is not as easy to be pluralist about number theory as it is about the higher set theory, agreeing that "God seems to have created a unique set of (positive) integers, but myriad variations on other structures." ${ }^{38}$ [emphasis in original] Presumably the truths about those unique integers are also unique and locked in and hence pluralism about arithmetic is untenable. 
Clarke-Doane's views on ethics differ from those advanced here principally in his assumption (of course widely shared) that ethics is essentially about practical decision-making - of deciding what to do. He says that any abstract principles in ethics would fail to determine what to do. ${ }^{39}$ It is true that there is a logical gap between "this natural ecosystem is inherently valuable" and "its being valuable is an ethical reason not to vandalize it", and another logical gap between that and "My decision is to vandalize it." Nevertheless the first bears on the second and the second on the third (for reasons the realist philosopher of ethics must explain, but which cannot be developed here). Since the present paper compares mathematical statements with axiological ethical statements like "this natural ecosystem is valuable" rather than conclusions of practical ethics like "I ought not to vandalize this ecosystem", Clarke-Doane's considerations about ethics are not directly relevant.

So Clarke-Doane's comparison of mathematics with ethics differs widely from the present one because of the different choices of paradigms in mathematics and ethics. His paradigms are respectively higher set theory and individual practical decisions. That is very unlike comparing, as here, axiology and arithmetic.

\section{Equality and Symmetry Arguments in Mathematics}

Equality is, paradigmatically, a central concept of mathematics. Mathematical writing is full of equations. Symmetry, central to algebra and mathematical physics, concerns the equality of parts of a system (in some respect such as shape). To have bilateral symmetry (the simplest form of symmetry) is just to consist of two parts equal in some respect; for example to be a palindrome is to have the second half of the text repeating the first in the opposite order.

The ability of arguments from symmetry to generate contentful propositions of (applied) mathematics is well illustrated in Archimedes' derivation of the law of the lever, an example 
which much impressed the creators of the Scientific Revolution and led to successful efforts to emulate it. ${ }^{40}$ Following it in detail (in a simple case) is useful for Platonic training of the soul in a mathematical necessity.

The law of the balance states that two weights on a beam supported by a fulcrum balance each other if the ratios of the weights is the inverse of the ratios of their distances from the fulcrum. That is, lighter weights far away can balance heavy weights closer in. Archimedes does not regard this as a physical law needing experimental support but offers to demonstrate it from absolutely certain first principles. In the simplest example, where one weight is twice the other, his proof works like this:

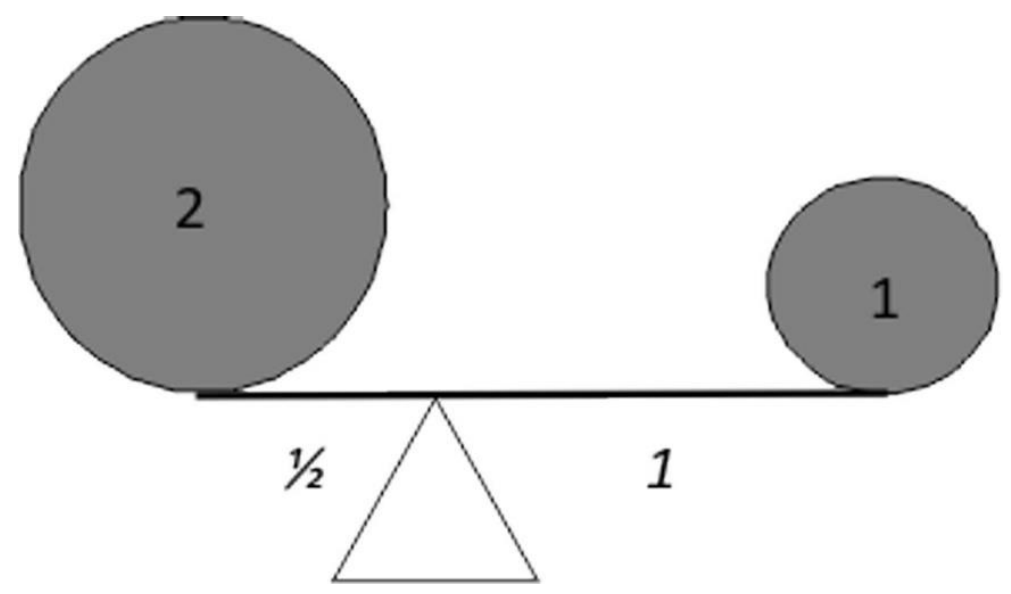

Fig 2a A weight of 2 close to the fulcrum balances a weight of 1 twice as far away

To prove that weights so positioned do balance, Archimedes first extends the (weightless) beam in each direction so that the fulcrum is now in the middle (the weights do not change position). 


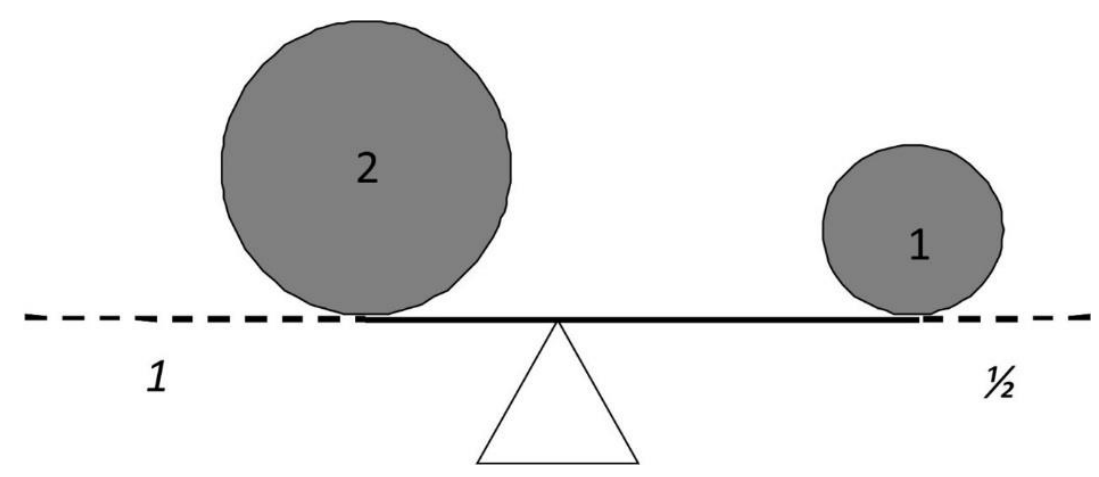

Fig $2 \mathrm{~b}$ The beam is extended so that the fulcrum is in the middle

The weights are now imagined as malleable, like clay, and are gently patted down to rest with uniform thickness on the beam, as in Fig 2c.

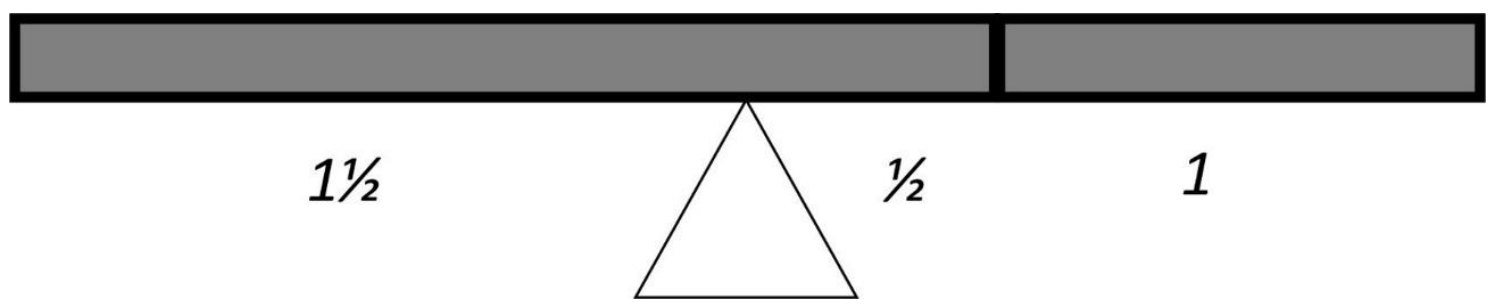

Fig $2 c$ The weights are patted down to rest uniformly on the beam

We see that in the final state, weight is uniformly distributed, with equal amounts each side of the fulcrum. So by symmetry the weights must balance. Therefore the original pair of weights must balance. All there is at the bottom of the argument is the equality of the pieces on each side of the fulcrum, which causes them to balance; "equal weights at equal distances are in equilibrium." That obvious and apparently innocuous principle of equality is parlayed by 
Archimedes' genius into a complex theory of contentful propositions about the balancing of unequal weights at unequal distances. ${ }^{41}$

The role of symmetry in mathematical physics has only increased since then, to the extent that "In the latter half of the 20th century symmetry has been the most dominant concept in the exploration and formulation of the fundamental laws of physics." 42

A mathematical example with perhaps even closer analogies to ethics is probability. As is well known, complicated questions about the probability of events in games with dice and cards are solved by counting the numbers of equiprobable outcomes. The probability of two dice giving a total of 2 (that is, of both showing 1 ) is $1 / 36$, while the probability of their giving a total of 3 (that is, one of them showing 1 and the other 2 ) is ${ }^{2} / 36$. The reason is that the first event consists of one of the 36 basic equiprobable outcomes of two dice (1 and 1), while the second event consists of two of them (1 and 2, and 2 and 1). It is the equiprobability of the basic outcomes that reduces problems in probability to the pure mathematics of counting. The equiprobability of the basic outcomes, it is agreed, results from a symmetry argument. Outcomes such as the 36 possible falls of two dice are equiprobable because there is in some sense a symmetry between them. Debate has been heated as to what this symmetry consists in - is it the physical symmetry of the dice? The equality of the long run observed relative frequency of outcomes? Our equal ignorance of the outcomes? Those are fair questions, but the calculation of outcomes does not depend on answering them. Provided the equiprobability of the basic outcomes is granted, they can be counted to give the probabilities of combinations of them.

As Pascal, the discoverer of mathematical probability, said, it is surprising that chance is subject to such strict mathematical methods: "by thus uniting the demonstrations of mathematics to the uncertainty of chance, and reconciling what seem contraries, it can take its 
name from both sides, and rightly claim the astonishing title: the Geometry of chance (aleae Geometria). ${ }^{, 43}$

The ability of symmetry principles to produce contentful truths about the worlds of physics and probability can act, in Platonic fashion, as an inspiration for ethics. If it is surprising that ethics is subject to symmetry arguments, it is no more so than that chance is.

\section{Equality and Symmetry Arguments in Ethics}

Ethics can follow applied mathematics into objectivist territory by also relying on symmetry arguments, or deductions from equality, provided it can give some minimal account of why the equality holds.

The best-known example of what might be called the "Archimedean spirit" in ethics, of deducing a complex ethical theory from a symmetry principle, is Rawls' Theory of Justice. Rawls regards distributive justice as dealing with "the way in which the major social institutions distribute fundamental rights and duties and determine the division of advantages from social cooperation." (Rawls, 1999, 6) He proposes to deduce just distributive arrangements from some assumptions about an "initial position," in which individuals must choose principles from behind a "veil of ignorance," which allows them self-interest and knowledge of general facts about human nature, but no knowledge of what position in society they will be born into. Rawls' model of deduction is a Euclidean one. "We should strive for a kind of moral geometry," he writes, "with all the rigor which this name connotes."44

Fundamental to the principles is equality: they are "the principles that free and rational persons concerned to further their own interests would accept in an initial position of equality as defining the fundamental terms of their association." 45 
Rawls denies to the participants in the initial position any substantive moral knowledge or conceptions of the good life. That throws even more weight on the pure symmetry between participants as bare moral agents, as Rawls recognizes. He writes,

the parties are symmetrically situated in the original position. This models our considered conviction that in matters of basic political justice citizens are equal in all relevant respects: that is, that they possess to a sufficient degree the requisite powers of moral personality and the other capacities that enable them to be normal and fully cooperating members of society over a complete life. Thus, in accordance with the precept of formal equality that those equal (similar) in all relevant respects are to be treated equally (similarly), citizens' representatives are to be situated symmetrically in the original position. ${ }^{46}$

On the question of where the equality comes from, Rawls' official position is that his concept of equality is "political, not metaphysical". Thus (as in discussions of the meaning of probability), he aims to retain the obviousness of and widespread agreement on equality without difficult discussions on what it is about humans that makes them equal. However, avoiding foundational inquiry entirely is rarely possible in philosophy, and Rawls does have a brief discussion of the "basis of equality" which gives a sketch of his answer. Asking why animals do not count as participants in the original position, he says that "equal justice is owed to those who have the capacity to take part in and to act in accordance with the public understanding of the initial situation." ${ }^{47}$ His use of "capacity" to extend rights beyond those who can actually understand to infants and the severely disabled indicates a degree of metaphysical stance on human nature.

Rawls' ambition is restricted to explaining political arrangements. It does not extend to ethics in general, such as the ethics of ordinary interpersonal relationships. Plainly bare and 
impersonal principles of equality are more suited to the discussion of political arrangements than to loving relationships between family and friends. Nevertheless, if we do look beyond the political realm, the principle of equality interacts with more substantive ethical principles and moderates how they work. We will look at a few brief examples.

Love, in its various senses, is central to ethics and is necessarily particular. Yet Jesus's call to "love your neighbour as yourself" expresses a widely-felt urge to include all within the ambit of loving behavior, such as charity, as far as possible. Natural and ethical ways in which one prefers and acts on behalf of one's family are properly restricted by laws against nepotism.

The substantive right to an education, based on allowing human rationality to be realized, implies educational actions, but not necessarily identical actions for each child. The circumstances of people matter, and they enter into the calculation. An equal right of children to a fair share of educational resources, for example, will require different actions in the cases of a musical or mathematical prodigy, a well-adjusted child of average intelligence, and an intellectually disabled child. All have rights to education, but the plans must be tailored to each child's abilities to profit from teaching, and one plan may cost more than another. That is typical of how variable circumstances interact with equality. (In Aristotle's mathematical language, the just distribution is proportional rather than numerically equal. ${ }^{48}$ )

Naturally, that leads to long debates on the detailed consequences of the principle of equality, with for example a need to resolve the tension between equality of outcomes and equality of opportunity, what weight should be given the claims of the worst off, and the like. Those debates cannot be settled simply by appealing the equality of persons. Nevertheless the ideal of equality is not vacuous. Appeals to equality of consideration are always very powerful. And that does not mean merely that equality is weighted heavily in comparison with other considerations. It means that any other consideration, such as skin colour or age or wealth, is 
by default of absolutely no weight, and the moral relevance of any consideration must be established in the face of the strong presumption against its relevance. Thus in the 1858 Lincoln-Douglas debates on slavery, Stephen Douglas was probably right as a matter of historical fact to claim that the writers of the Declaration of Independence had only had white men in mind in "all men are created equal," but Abraham Lincoln's case that the logic implied equality for all prevailed. ${ }^{49}$

"Our" (post-Christian and post-Enlightenment) ethics has become egalitarian in principle, to the extent that "The principle of equal dignity and respect is now accepted as a minimum standard throughout mainstream Western culture." ${ }^{, 50}$ But it should not be forgotten that ethics without a principle of the equality of persons is possible and has been commonplace historically. As we saw, ancient Greek ethics was barely aware of such a principle, and so Plato's and Aristotle's ethics is alien to ours. Slave-owning societies of course recognized no such principle. In contemporary ethics, the most prominent denier of the principle is Peter Singer. Singer's ethics is very mathematical, rigorously deduced from $a$ principle of equality, but not the equality of persons. It rests on the "basic principle of equality: the principle of equal consideration of interests." All interests are equal; "an interest is an interest, whoever's interest it may be." ${ }^{, 1}$ Thus, an animal's pain is entitled to equal consideration to an equal pain in a human. That principle has been responsible for Singer's controversial and radical departures from traditional ethics, such as his defence of the permissibility of infanticide for healthy babies. "The preference utilitarian reason for respecting the life of a person cannot apply to a newborn baby. A newborn baby cannot see itself as a being which might or might not have a future, and so cannot have a desire to continue living." ${ }^{, 52}$ Singer's preference utilitarianism counts interests (as equal) in abstraction from the beings whose interests they are, and the latter do not count morally in themselves. 
These dramatic implications of divergence from a principle of equality of persons reveal the moral significance of the principle itself. It is neither meaningless nor vacuous nor infinitely flexible. Nor is it widely agreed, if we speak cross-culturally and cross-temporarily.

\section{Mathematising Vice: Game Theory and Replacements for Ethics}

There is a dark side to the relation of mathematics to ethics. Insights into mathematics can be use in ways productive of evil. Mathematical models such as those just discussed, which implement a realist philosophy of ethics, can be better understood by contrasting them with models whose purpose is to undermine ethical realism by setting up an alternative model of the behavior we normally call ethical. They model humans as a different and non-moral kind of entity, such as a purely self-interested economic actor, or a tool of selfish genes, and attempt to generate a system of behavior which mimics and replaces ethics.

Best-known are the economic theories in which the individual human involved in economic activity is modelled as homo economicus, a lone consumer regarded as self-interested and rational enough to pursue his/her interests optimally. But the relation of this perspective to an ethical one is ambiguous. While the rhetoric of "self-interest" suggests that agents do not act ethically in the interests of others, that is not essential to the model, whose primary aim is to explain collective economic behavior in terms of agents' actual interests. Actual interests may be either genuinely ethical or not. An interest in children's education can produce a market in school fees and an interest in philanthropy can produce a market in charitable services as easily as a desire for fast cars can produce a market in Lamborghinis. ${ }^{53}$ Economic models of this kind are therefore not as contrary to an objective moral stance as supposed by their political opponents who accuse them of "rampant individualism". 
It is otherwise with evolutionary models of ethical behavior, which really are corrosive of realist ethics.

The Darwinian theory of evolution initially had a problem with explaining altruistic behavior in organisms, since it was mysterious how altruistic and even self-sacrificing traits could have evolved in natural competition "red in tooth and claw". From the mid-twentieth century, a number of "inclusive fitness" and "selfish gene" mathematical models of evolution explained how natural selection could favour altruism, through such mechanisms as organisms sacrificing themselves for conspecifics with whom they shared genes.

While those theories were strictly scientific and so should have implied no "oughts", it soon became evident that they offered exciting possibilities for explaining ethics away. Altruistic behavior, in these models, is driven not by any moral considerations but by an organism's acting as a puppet of "selfish genes" or some other purely causal evolutionary force. ${ }^{54}$ If (apparently) ethical behavior like altruism is an inevitable effect of natural selection pressures, "morality is seen as the unintended side-effect of the interactions of agents." $"$ So it seems to be explained without remainder in terms of natural causes, leaving no role for anything objectively ethical that could judge some evolved behavior as wrong. Evolutionarily evolved behaviors (and beliefs) would not be expected to "track" objective moral truths, if there were any, and hence the posit of objective ethical truths would be a "spare wheel" that might as well be dispensed with. ${ }^{56}$ Moral "error theorists" seized on that implication as a confirmation of their view that the whole idea of ethics is a mistake. ${ }^{57}$

It soon also became evident that parallel explanations were inevitable of behaviors which lacked the rosy moral glow of altruism. Martin Nowak's work on the mathematics of evolutionary game theory explains the rise of cooperation, but points out that tribal warfare and nepotism are also behaviors that would be expected to arise from organisms favouring the 
conspecifics who most share their genes. ${ }^{58} \mathrm{He}$ does not mention that rape and genocide are equally efficient means of increasing the frequency of one's genes in subsequent generations, techniques taken advantage of by Genghis Khan to produce an estimated 16 million living descendants. ${ }^{59}$ The most salient indicator of who one shares genes with is race, so racism is also a behavior to be expected as a result of evolution. ${ }^{60}$

But rape, racism and genocide are evils and their role in evolution is entirely incapable of providing an excuse for them. As moral realists point out, to explain morality wholly in terms of evolved strategies is to leave oneself without a standpoint from which to evaluate a behavior such as altruism as good and one such as genocide as bad.

The comparison of realist and anti-realist mathematical models of ethics therefore shows that a devotion to mathematics is not, as Plato seems to suggest, automatically productive of insight into the Good. Mathematics in relation to ethics can be used for good or ill. Realism about ethical realities needs to be imported into the philosophy of ethics from a source outside mathematics itself (for example, from an insight into the worth of persons).

\section{Conclusion}

W.D. Ross wrote in 1930:

That an act, qua fulfilling a promise, or qua effecting a just distribution of good, or qua returning services rendered, or qua promoting the virtue or insight of the agent, is prima facie right ... is self-evident just like a mathematical axiom, or the validity of a form of inference, is evident. The moral order expressed in these propositions is just as much part of the fundamental nature of the universe (and, we may add, of any possible universe in which there were moral agents at all) as is the spatial or numerical structure 
expressed in the axioms of geometry or arithmetic. In our confidence that these propositions are true there is involved the same trust in our reason that is involved in our confidence in mathematics; and we should have no justification for trusting it in the latter sphere and distrusting it in the former. In both cases we are dealing with propositions that cannot be proved, but that just as certainly need no proof. ${ }^{61}$

Since then, many relativist and historicist currents have undermined that kind of robust belief in the absolute objectivity of ethical truths. Those currents have had less success with undermining belief in mathematical truths, and earlier philosophies of mathematics that dismissed mathematics as a mere language or heap of tautologies have waned. Leading philosophies of mathematics are realist, supporting Ross's view that the mathematical structure of the universe is part of its fundamental and necessary nature and that the most central truths describing it are knowable with certainty. The parallels between mathematics and ethics suggest that the same can be said of the ethical structure of reality, thus reviving the essentials of Plato's view that mathematics is the ideal body of knowledge for inducing in the soul an understanding of ethical truths.

\section{Declarations}

Funding: none received. Conflicts of interests: none

\section{Notes}

\footnotetext{
1 "Realism" and "objectivity" are here taken in standard though contested senses: "Realism" about (purported) entities is the thesis that they exist and are independent of anyone's beliefs, linguistic practices, conceptual schemes etc (A. Miller, "Realism,” Stanford Encyclopedia of Philosophy 2002/2019); "objectivity” is then an aspect of realism, namely the human-independent truth of the facts about those entities. Thus for paradigmatic moral or mathematical realism as defended here, "realism" and "objectivity" go together. For other views, that is
} 
less clear; for example, if one secured uniqueness of moral propositions by their being enacted by the Supreme Court, that could be called a kind of objectivity without realism. The somewhat different meanings of the two terms in J. Clarke-Doane, Morality and Mathematics (Oxford: Oxford University Press, 2020), according to which objectivity and realism can be in tension, arise from his views on pluralism and the role of ethics in decisions and will be considered briefly in section 5 .

2 J. Lear, "Ethics, mathematics and relativism," Mind 92 (1982): 38-60; J. Franklin, “On the parallel between mathematics and morals," Philosophy 79 (2004): 97-119.

${ }^{3}$ C. Peacocke, "Moral rationalism,” Journal of Philosophy 101 (2004): 499-526.

${ }^{4}$ A.C. Baier, "What do women want in a moral theory?" Noûs 19 (1985): 53-63.

${ }^{5}$ P. Singer, Introduction, in P. Singer (ed), Ethics, (Oxford: Oxford University Press, 1994), 3-13, but largely withdrawn in K. de Lazari-Radek and P. Singer, The Point of View of the Universe: Sidgwick and Contemporary Ethics (Oxford: Oxford University Press, 2014), chs. 3-5.

${ }^{6}$ A. Musgrave, “Logicism revisited,” British Journal for the Philosophy of Science 28 (1977): 99-127, section 2; N. Tennant, “Logicism and neologicism,” Stanford Encyclopedia of Philosophy, (2013/2017), section 6.

${ }^{7}$ For example Clarke-Doane, Morality and Mathematics; J. Clarke-Doane, "The ethics-mathematics analogy," Philosophy Compass, 15 (1) (2020), e12640; some contributions in U.B. Leibowitz, and N. Sinclair (eds), Explanation in Ethics and Mathematics: Debunking and Dispensability (Oxford: Oxford University Press, 2016).

${ }^{8}$ Plato, Republic 527e; a contemporary version in F. Su, Mathematics for Human Flourishing (Yale: Yale University Press, 2020).

${ }^{9}$ H.D. Saffrey, “Ageômetrêtos mêdeis eisitô: une inscription légendaire,” Revue des études grecques 81 (1968): $67-87$.

${ }^{10}$ Plato, Republic 510d-511a.

${ }^{11}$ M. Giaquinto, Visual Thinking in Mathematics (Oxford: Oxford University Press, 2007), ch. 4; A.G.

Newstead and J. Franklin, “The Epistemology of Geometry I: The Problem of Exactness,” ASCS09:

Proceedings of the 9th Conference of the Australasian Society for Cognitive Science, Macquarie University, Sydney, 2009.

${ }^{12}$ For “theory laden" moral perception, see G. Harman, "Ethics and observation," in The Nature of Morality: An Introduction to Ethics (New York: Oxford University Press, 1977), ch. 1, and subsequent debate such as Sarah McGrath, Moral Knowledge (Oxford: Oxford University Press, 2020), ch. 4; for the perception of mathematical 
necessities, C. Legg and J. Franklin, "Perceiving necessity," Pacific Philosophical Quarterly 98 (2017): 320343.

${ }^{13}$ The idea of equality from birth (for citizens) does appear in an obscure dialogue of Plato in a speech attributed to Aspasia (Menexenus 238e-239a). But it plays no role in the main body of Plato's thought.

${ }^{14}$ On the "foreign" nature of Greek ethics see A.W.H. Adkins, Merit and Responsibility: A Study in Greek Values (Chicago: Chicago University Press, 1975).

${ }^{15}$ M.F. Burnyeat, "Plato on why mathematics is good for the soul," Proceedings of the British Academy 103 (2000): 1-81, section 10 .

${ }^{16}$ Plato, Republic 531.

${ }^{17}$ Republic 443d-e.

${ }^{18}$ R. Demos, "Plato's idea of the Good," Philosophical Review 46 (1937): 245-275, at 261; I. Robins, "Mathematics and the conversion of the mind: Republic VII 522c1-531e3," Ancient Philosophy 15 (1995): 359391.

${ }^{19}$ Plato, Timaeus 33b.

${ }^{20}$ Aristotle, Nicomachean Ethics 1130b-1132b; M. Balinski, "What is just?" American Mathematical Monthly 112 (2005): 502-511.

${ }^{21}$ Republic 504d.

${ }^{22}$ Thomas Aquinas, Summa Theologiae, book I q. 39 art. 8.

${ }^{23}$ U. Eco, The Aesthetics of Thomas Aquinas, trans. H. Bredin (Cambridge, Mass: Harvard University Press, 1988), 82-98.

${ }^{24}$ One might ask also if the relation of ethics to mathematics is symmetrical: could ethical realism inspire mathematical realism? While that is not likely after two millennia where mathematical knowledge progressed massively while ethics remained mired in foundational debates, it is conceivable that it did in a much earlier era when mathematics was undeveloped. Indeed, the earliest mathematical writings were for accountancy, which quantifies certain kinds of obligations (to transfer goods or money). The desirability of exact quantification to prevent disputes drives accountancy as a form of "computational casuistics" (J. Franklin, Accountancy as computational casuistics, Business \& Professional Ethics Journal 17 (4) (1998): 21-37).

${ }^{25}$ Plato, Republic 527a-b.

${ }^{26} \emptyset$. Linnebo, Platonism in the philosophy of mathematics, Stanford Encyclopedia of Philosophy (2009, revised 2018). 
${ }^{27}$ J. Franklin, An Aristotelian Realist Philosophy of Mathematics: Mathematics as the science of quantity and structure (Basingstoke: Palgrave Macmillan, 2014).

${ }^{28}$ Franklin, Aristotelian Realist Philosophy of Mathematics, 48-49; T. Räz, “Euler's Königsberg: the explanatory power of mathematics," European Journal for Philosophy of Science 8 (2018): 331-346.

${ }^{29}$ J. Franklin, “Mathematical necessity and reality,” Australasian Journal of Philosophy 67 (1989): 286-294.

${ }^{30}$ G.E. Moore, Principia Ethica (Cambridge: University Press 1903), preface.

${ }^{31}$ I. Kant, The Metaphysics of Morals (1797), 6:435, trans. M. Gregor (Cambridge: Cambridge University Press, 1991), 186; this realist interpretation of Kant defended in A. Wood, Kant's Ethical Thought (New York:

Cambridge University Press, 1999), e.g. 157-8.

32 J. Hacker-Wright, "Virtues as perfections of human powers: on the metaphysics of goodness in Aristotelian naturalism,” Royal Institute of Philosophy Supplements 87 (2020): 127-149.

${ }^{33}$ N. Wolterstorff, Justice: Rights and Wrongs (Princeton: Princeton University Press, 2008), especially ch. 13.

${ }^{34}$ Clarke-Doane, Morality and Mathematics, 176.

${ }^{35}$ Clarke-Doane, Morality and Mathematics, 176.

${ }^{36}$ B. Russell, "The Regressive Method of Discovering the Premises of Mathematics," (1907), in B.Russell, Essays in Analysis (London: Allen and Unwin, 1973), 272-283, quoted in Clarke-Doane, Morality and Mathematics, 45; argued at length in P. Maddy, "Believing the axioms," Journal of Symbolic Logic 53 (1988), $481-511$.

${ }^{37}$ An account of how proof works in elementary mathematics in J. Franklin and A. Daoud, Introduction to Proofs in Mathematics (New York: Prentice Hall, 1988).

${ }^{38}$ Clarke-Doane, Morality and Mathematics, 179.

${ }^{39}$ Clarke-Doane, Morality and Mathematics, 166-7.

${ }^{40}$ E. Vampoulis, "Archimedes in seventeenth century philosophy," in The Genius of Archimedes: 23 centuries of influence on mathematics, science and engineering, ed. S.A. Paipetis and M. Ceccarelli, (Dordrecht: Springer, 2010), 331-43.

${ }^{41}$ Archimedes, On the Equilibrium of Planes, in T.L. Heath, ed, The Works of Archimedes. (Cambridge: University Press, 1897), 189-220, book 1 proposition 6; discussion in J. Franklin, "Early modern mathematical principles and symmetry arguments," in P. Anstey (ed), The Idea of Principles in Early Modern Thought (New York: Routledge, 2017), ch. 1. 
${ }^{42}$ D.J. Gross, "The role of symmetry in fundamental physics," Proceedings of the National Academy of Sciences 93 (1996): 14256-14259.

${ }^{43}$ B. Pascal, Address Celeberrimae Matheseos Academiae Parisiensi (1654), in Oeuvres complètes, ed. J. Mesnard (Bruges: Desclée de Brouwer, 1964-70), vol. 2, 1034-5.

${ }^{44}$ J. Rawls, A Theory of Justice, revised ed. (Oxford: Oxford University Press, 1999), 105, though he admits ethics is not in that state yet: discussion in M.B. Gill, "Morality is not like mathematics: the weakness of the math-moral analogy," Southern Journal of Philosophy 57 (2019): 194-216.

${ }^{45}$ Rawls, Theory of Justice, 10)

${ }^{46}$ J. Rawls, Justice as Fairness: A Restatement (Cambridge, Mass: Harvard University Press, 2001), 18.

${ }^{47}$ Rawls, Justice as Fairness, 442; full discussion in J. Waldron, One Another's Equals: The Basis of Human Equality (Cambridge, Mass: Harvard University Press, 2017).

${ }^{48}$ Aristotle, Nicomachean Ethics 1130b-1132b.

${ }^{49}$ Discussion in P. Westin, "The meaning of equality in law, science, math, and morals: a reply," Michigan Law Review 83 (1983): 604-663.

${ }^{50}$ S. Gosepath, Equality, Stanford Encyclopedia of Philosophy (2001/2007), section 2.3, with brief history.

${ }^{51}$ P. Singer, Practical Ethics, $2^{\text {nd }}$ ed. (Cambridge: Cambridge University Press, 1993), 21.

${ }^{52}$ Singer, Practical Ethics, 171.

${ }^{53}$ Discussion in E. Anderson, "Beyond homo economicus: new developments in theories of social norms," Philosophy \& Public Affairs 29 (2000): 170-200.

${ }^{54}$ R. Wright, The Moral Animal: Evolutionary Psychology and Everyday Life (New York: Vintage, 1995).

${ }^{55}$ B. Verbeek, and C. Morris, Game theory and ethics, Stanford Encyclopedia of Philosophy, (2004/2010), section 7 .

${ }^{56}$ G. Harman, The Nature of Morality: An Introduction to Ethics (New York: Oxford University Press, 1977_), 3-10; G. Kahane, "Evolutionary debunking arguments,” Noûs, 45 (2011): 103-125; S. Street, "A Darwinian dilemma for realist theories of value," Philosophical Studies 127 (2006): 109-166; K. Vavova, "Evolutionary debunking of moral realism," Philosophy Compass 10 (2015): 104-116.

${ }^{57}$ R. Joyce, The Evolution of Morality (Cambridge, Mass: MIT Press, 2006).

${ }^{58}$ M. Nowak and R. Highfield, SuperCooperators: Altruism, Evolution and Why We Need Each Other to Succeed (New York: Free Press, 2012), chs. 4-5. 
${ }^{59}$ T. Zerjal, et al. "The genetic legacy of the Mongols," American Journal of Human Genetics 72 (2003): 717721; discussion of the issue in R. Thornhill, and R.T. Palmer, A Natural History of Rape: Biological Bases of Sexual Coercion (Cambridge, Mass: MIT Press, 2000) and subsequent controversy.

${ }^{60}$ J.P. Rushton, "Ethnic nationalism, evolutionary psychology and Genetic Similarity Theory,“" Nations and Nationalism 11 (2015): 489-507.

${ }^{61}$ W.D. Ross, The Right and the Good (Oxford: Clarendon, 1930), 29-30; further 32-4. 